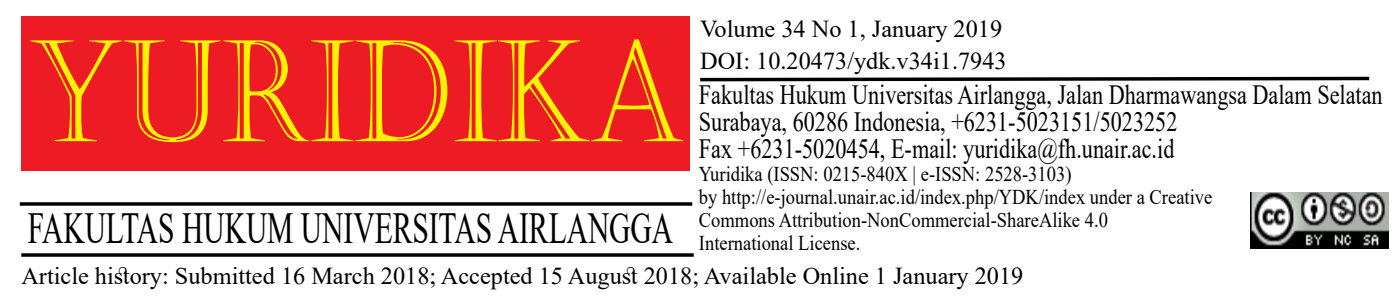

\title{
Victim's Involvement Model in Children Legal Process Based on Law No. 11/2012 on Children Criminal Justice System
}

\author{
Oheo K. Haris and Ali Risky \\ oheokh@gmail.com \\ University of Halu Oleo
}

\begin{abstract}
The enactment of Law N0. 11/2012 on Children Criminal Justice System is a new hope for the rights of the victims of a crime. This Law has given a huge opportunity to the victims by means of the concept of restorative justice. This paper seeks to offer a model of victim's involvement which is implementable either outside or inside of the judicial system. Firstly, accessibility for the victim in this law has placed the concept of restorative justice. The model of restorative justice offered in this law is the gate for the crime victim who fought for their rights. Restorative justice was essentially stands between the victim and the offender and focuses on the effects of crimes. Secondly, the term diversion is the transfer of resolution for the process of the juvenile case from the judicial system to outside of the criminal system. Togetherness for all of the involved groups is a better solution in certain case as it can solve problem and create better unprecedented bindings. This attempt is in order to seek solution, reconciliation, and not to seek revenge for a criminal offence. Thirdly, victim's invovelment in criminal system allows for witnesses to come forward. But they should have legal protection and should avoid bad label. The next model is an opportunity for the juvenile victism before the court handing down the verdict.
\end{abstract}

Keywords: Victim's Involvement; Children Legal Process; Children Criminal 


\section{Introduction}

In the last few decades the problem of victims of crime has become an interesting concern especially in practical and theoretical levels. In the academic level, the problems of victims of criminal acts are examined through scientific studies referred to as victimology. ${ }^{1}$ The problem of victims of criminal acts is interesting to discuss, because victims based on their characteristics can be the main trigger for criminal acts or less attention is given to the interests of victims of criminal offenses. The problem of victims of crime if associated with the criminal justice system, this is also an interesting matter to discuss as there are no regulations on how victims of criminal acts are involved in settling criminal cases.

In an impulsive manner, the state represents victims and related citizens in terms of prosecution and implementation of court decisions that are commensurate with criminal offenders. This shows that overall, victims of crime have not been able to obtain their rights in relation to legal procedures. Thus, Indonesia as a rule of law state, which, in accordance with criminal procedure law, should care about the rights of victims of crime without any sense of revenge, coercion and unilateral actions (eigen rechting). ${ }^{2}$

The public prosecutor has always been perceived as a victim, because in the trial they represented the victim and the state in the prosecution. The public prosecutor always feels that they represent the victim even though sometimes the does not pay attention to the interests of the victim in carrying out the legal process. If the interests of the victims are not addressed in the judicial process, it could have an impact on the values of justice produced by the judicial process itself. This can be reflected through court decisions that are sometimes felt to be unfair by the victim or the accused.

Whereas if we refer to Law No. 8/1981 on the Criminal Procedure Code (KUHAP) which applies today for the interests of the community, especially in

\footnotetext{
1 In terminology, Victimology according to Hugo Reading, is a science that analyzes the existence of victims, triggers the emergence of victims, as well as the impact of the emergence of victims and describes real problems for the social Dikdik M Haris Mansyur And Elisatris Gultom, Urgency for Protection of Victims of Crime: Between Norms and Reality (Raja Grafindo 2008).[76]

2 Bambang Waluyo, Viktimologi Proteksi Saksi Dan Korban (Sinar Grafika 2012).[2-3]
} 
relation to the rights of victims of crime, it turns out that the Criminal Procedure Code has not accommodated the interests of victims. Though the direction of criminal law policy (including criminal procedural law) is to provide legal protection to citizens in order to realize their welfare (social welfare) ${ }^{3}$ The lack of attention for victims of criminal acts especially in the Criminal Procedure Code certainly has implications for the interests of the victims themselves. There are only two forms of victim involvement in the criminal justice system. First, when the victim is made as a "Witness of the Victims" from the investigation process to the Judge's decision. This is also not clearly accommodated in the Criminal Procedure Code, because of the types of evidence in the Criminal Procedure Code that do not recognize the "Witness of Victims" which are only "Witness Information". ${ }^{4}$ So it is not an exaggeration to say that the position of victims is very weak in the context of the Indonesian Criminal Justice System. The statement certainly has legal reasons as stipulated in Article 184 of the Criminal Procedure Code which stated that evidence of victims of criminal acts is often placed as a statement of victim witnesses before the Judge. It is no exaggeration to say that the position of victims in legal courts in Indonesia is only an object of the judicial process.

Secondly, in the Criminal Procedure Code there is a chapter on the unification of compensation claim cases. In the mechanism of unification the problem of victims may request a compensation on what they have felt as the result of crime act. The disadvantage here is that material losses are not immaterial losses. ${ }^{5}$ The procedure for unification of compensation claims is a characteristic of Indonesian law which may not be found in other countries. Even if it is not in practice, it is rarely applied so that it seems ineffective. ${ }^{6}$ Once again it appears that the public prosecutor does not really represent the victim by not using the mechanism of combining compensation

\footnotetext{
3 Wisnubroto and Widiartana, Pembaharuan Hukum Acara Pidana (Citra Aditya Bakti 2005).[13].

4 See Article 184 section 1 of Law No. 8/1981 on the Criminal Procedure Code (KUHAP)

5 See Article 98-101 of Law No. 8/1981 on the Criminal Procedure Code (KUHAP).

6 Rena Yulia, 'Mengkaji Kembali Posisi Korban Kejahatan Dalam Sistem Peradilan Pidana' (2016) 28 Mimbar Hukum <https://jurnal.ugm.ac.id/jmh/article/view/15858/10467>.[34-44].
} 
claims. Thus the interests of the victims have fulfilled the respect of Human Rights as perpetuated in the Indonesian constitution. The second principle of the Pancasila, implicitly suggests that the Indonesian state respects human rights. This principle upholds the value of equal rights and obligations among citizens. On the contrary, this also rejects discrimination, prevents the disintegration of the nation, and keeps intolerant attitudes away. ${ }^{7}$

This form of substitution of losses cannot yet reflect legal protection for victims of criminal acts. Seeing the problem of victims who have less attention in the criminal justice system certainly requires a criminal reform (formal reform) in terms of providing legal protection against victims and the forms of access and involvement of victims in the criminal justice system. In contrast to what was stated earlier, the description of the accessibility of victims of criminal acts in the criminal justice system began with the enactment of Law No. 11/2012 on Children Criminal Justice System, which is a breath of fresh air for victims of criminal acts. The access and involvement of victims of criminal acts in Law No. 11/2012 used not only in the settlement of cases through criminal justice processes but also through processes outside of criminal justice. Of course this is a paradigm shift in criminal law which means that criminal law is not only focused on offender but it also victim-oriented. Several provisions of Law No. 11/2012 regulate the access and forms of involvement of "victims" in general and "child victims" in particular. This paper examines the access and form of victim involvement in the Children Criminal Justice System, the intended involvement both at the stage of investigation, prosecution and trial in the context of legal protection and fulfillment of victims' rights both in the court settlement process and outside the court. By type, this study is a normative legal research or library research that focuses on positive legal norms in the form of legislation and research that relies on literature as the main data.

By nature, this research is a prescriptive legal research, namely research that describes the access and forms of victim involvement in the Children Criminal

\footnotetext{
7 Ig Punia Atmaja Nr, 'Penyiaran Berita Kriminal Dalam Kerangka Proteksi Hak Tersangka Atau Terdakwa' (2017) 32 Yuridika <https://e-journal.unair.ac.id/YDK/article/view/4853>.[2].
} 
Justice System, the intended involvement both at the stage of investigation, prosecution and trial in the context of legal protection and fulfillment of victims in the process of resolving cases in court and outside the court. In order to provide a complete and clear description, several approaches are used in conducting research such as the statute approach ${ }^{8}$ which aims to review all laws and regulations that have a direct connection with Law No. 11/2012, the conceptual approach is to move from the views and doctrines that develop in legal science, especially criminal law.

As with normative legal research generally based on secondary data as the main data, secondary data is divided into primary legal materials, secondary legal materials, and tertiary legal materials. Primary legal material consists of legal material obtained from the laws and regulations and judges' decisions. Secondary legal material is legal material obtained from library literature in the form of law books, scientific articles, papers. Whereas tertiary legal material is legal material obtained from dictionaries, encyclopedias and cumulative indexes.

The method of collecting data in normative legal research is carried out by library research on legal materials, primary, secondary and tertiary legal materials. These legal materials are then chosen to be read and which legal materials are relevant to the context of this research, namely about access and forms of victim involvement in Law No. 11/ 2012. All legal materials that have been compiled later in the inventory are classified, then processed and analyzed comprehensively, so conclusions can be drawn from the results of the analysis.

\section{Understanding of Victim Access in Law No. 11/2012}

According to Arif Gosita, ${ }^{9}$ a victim is anyone who experiences physical and spiritual suffering for the impact of another person's actions aimed at obtaining personal benefits that are very contradictory to human rights. In line with the crime dictionary dictionary cited by Abdussalam then followed by Bambang Waluyo, a victim is "a person who has experienced physical misery or mental pain, destruction

\footnotetext{
8 Peter Mahmud Marzuki, Penelitian Hukum (Revisi, Kencana Prenada Media Group 2013).[35].

9 Arif Gosita, Masalah Korban Kejahatan (Akademika Presindo 1993).[41].
} 
of ownership or causes of death for an act or effort of minor error by criminals. ${ }^{10}$ Victims in the criminal justice system can be a key to unlocking the truth that will be revealed in the trial, but also a decision deems fair by a court can viewed as very unfair by the victims as they think their interests have not been taken care of by the criminal justice process.

The urgency of the analysis of the existence of victims on the other hand also describes the relationship between victims and offenders, in addition to assessing criminal procedures including determining the responsibility of criminals, further in determining the form and magnitude restitution or compensation to be received by the victim. ${ }^{11}$ Discussing crimes against the victim, one must first understand the status of the rights and obligations of the victim. Furthermore, the position of the victim has an influence on the size of the rights and obligations contained in criminal acts. The form of benchmarks in the judge's decision in determining the rights and obligations of the victim is the level of involvement and functional responsibility of the victim in a crime. ${ }^{12}$ Arif Gosita further elaborates on a number of things that are victims' rights in every criminal justice process:

1. The victim has the right to obtain restitution/compensation for what he experiences based on the level of participation in a crime;

2. The victim has the right to compensation for himself with the consideration that he rejects all forms of restitution;

3. The victim uses his rights in the sense that as an heir will inherit to his descendants;

4. The victim applies his rights in the context of obtaining restitution;

5. The victim receives his rights to his property;

6. The victim has the right to call as a witness who actually threatens his life;

7. The victim obtains legal guarantees if his position is as a complainant for a criminal act;

8. Victim must be provided with legal advocacy. Victims have the right to appeal from the lower level to a higher level (rechtmiddelen). ${ }^{13}$

Explicitly Law No. 11/2012 gives 2 types of victims, namely victims and child

\footnotetext{
${ }^{10}$ Bambang Waluyo (n 2).Op.Cit.[9].

${ }_{11}$ Adhi Wibiwo, Proteksi Hukum Korban Amuk Massa Sebuah Tinjauan Viktimologi (Thafa Media 2013).[30].

${ }_{12}$ Arif Gosita, Masalah Proteksi Anak (Akademika Presindo 1989).[86].

13 ibid.[52-53]
} 
victims. "Victim" is a victim in general and has grown up in accordance with the definition stated above, while understanding the child as a victim is someone who has not reached eighteen years who is also a victim of a crime ${ }^{14}$ At the beginning of Law No. 11 of 2012 has also been emphasized on the restoration of justice, where the solution must include the involvement of crime makers, victims, relatives/brothers, both makers of crime and victims. things are certainly done in order to realize the best solution for both parties. In addition, this avoids revenge. Understanding the formulation of restorative justice we can conclude two things: first it appears that the victim began to be involved in solving the problem of crime; the second direction of restoration of justice is to restore the situation as before between the makers of criminal acts and victims. The most important thing in overcoming crime is to open a room for parties (crime makers and victims). Besides that, this process also prioritizes a value and direction in order to find a situation in the past and applied punishments that characterize and anticipate. The response to violations of legal norms is part of the procedure for applying punishment. ${ }^{15}$

The term Albert Eglash's restorative justice in 1977, which tried to distinguish three forms of criminal justice, is retributive justice, distributive justice and restorative justice, respectively. The retributive justice approach is to punish the offender for the crimes committed by him. While distributive justice has the purpose of rehabilitating the perpetrators. In principle, justice restoration is to bring together the makers of crime and victims that lead to the recovery of the victims as well as to obtain the rehabilitation of crime makers. ${ }^{16}$ Restorative justice is not only based on the relationship of victims, but also includes citizens including the makers of the crime itself. The context of criminal sanctions is always based on 4 elements as follows, among others: victims of criminal acts, citizens, government and crime makers. ${ }^{17}$ It can be said that there is a shift in the paradigm of retributive justice to

\footnotetext{
${ }^{14}$ Article 1 section 4 of Law No. 11/ 2012 Children Criminal Justice.

15 Karim, 'Tanggung Jawab Pelaku Pidana Pelanggaran Dalam Perspektif Restorative Justice' (2016) 31 Yuridika <https://e-journal.unair.ac.id/YDK/article/view/4787>.[2-3].

16 O.S. Hiariej, Prinsip-Prinsip Hukum Pidana (Universitas Atma Jaya 2014).[3].

17 Siswanto Sunarso, Viktimologi Dalam Sistem Peradilan Pidana (Sinar Grafika 2012).[45].
} 
restorative justice. Listening to social environment growth, the shift will lead to renewal in order to create prosperity for future citizens. ${ }^{18}$ It is through this type of restorative justice that the victim can obtain full rights, as well as the rights that the author stated earlier. So the writer can say that the restorative justice model is the entrance or access for victims of criminal acts to obtain their rights in the juvenile justice system.

\section{Form of Victim's Involvement Outside of Children Criminal Justice}

The final basis illustrates that legal protection in the justice system in Indonesia has opened up opportunities for child victims to settle cases outside the court. This concept aims to resolve criminal cases that it faces with child offenders. Settlement outside the criminal court in question is a concept called Diversion. Referring to the regulation, the definition of diversion is to find a solution by diverting problems that are directly related to the child from going outside the court. In other words, this diversion theory is the realization and actualization of the concept of justice for restoration. The expected output is to restore the situation as before without having to apply the concept of retaliation. In addition, this concept is also to unite all parties, especially the specific substance of crime and to bring together both personal and communal, which then gives birth to rights and obligations without setting egocentricity. ${ }^{19}$

In principle, this diversion application also prioritizes the familial approach that is commonly also called non-reason which leads to improvement. ${ }^{20}$ In order to correct the mistake, the child who becomes the perpetrator of the crime is met with the victim of the crime and other interested parties. The concept of diversion applies to victims and children of victims by their guardian parents. Of course in 2012).[1]

18 Teguh Prasetyo and Abdul Halim Barkatullah, Politik Hukum Pidana (Pustaka Pelajar

19 Explanation of Law No. 11/2012 on Children Criminal Justice System.

${ }^{20}$ Marlina, 'Penerapan Konsep Diversi Terhadap Anak Pelaku Tindak Pidana Dalam Sistem Peradilan Pidana Anak' (2008) 13 Jurnal Equality <http://repository.usu.ac.id/bitstream/handle/123456789/18420/equ/-feb2008-13 (5).pdf;jsessionid=6ACBDA73585C95838A9E82A2DF$\mathrm{B} 3 \mathrm{EC} 16$ ? sequence $=1>$. 
this case the purpose held according to Law No. 11 of 2012, one of which is to achieve peace between victims and offenders. Peace between victims and children of criminal offenders becomes very important because it can be through peace that the psychological burden of the victim can be reduced by the loss of traumatic events, on the other hand the peace produced through this diversion is also reduced and of course eliminates revenge on each side.

This diversion of ideas and ideas is carried out by means of agreement which directly involves children as criminals and their families, community leaders, scholars, officials and policy makers. Based on this deliberation to reach consensus, a meeting point is reached towards the problems of victims and offenders. Through this deliberation process, the victims can fulfill their rights, considering that diversion also pays attention to the interests of the victims. The interests of the victims certainly cannot be separated from how to recover back to what they experienced. The author's recovery is in the form of returning losses to victims achieved through an agreement between the victim and the victim's child. The concept of diversion also in Law No. 11 of 2012 is not necessarily carried out even though it is stated that diversion must be pursued at every stage of the criminal justice system, whether investigations, prosecutions, trials but joint diversion decisions must obtain legitimacy on the willingness of child victims. Here it can be seen that the victim has the authority whether to give consent to the diversion process or not and give approval whether to do diversion or not in other words continue the case to court. If we look at the provisions regarding diversion, we can see that the victims through the diversion process are very open to the opportunity for victims to fulfill their interests in obtaining their rights as victims.

\section{Forms of Victim's Involvement in Children Criminal Justice}

Before further discussing about the form of Access and Relationship of Victims in the Child Criminal Justice Process the author will first describe a little understanding of the criminal justice system according to experts. The definition of a criminal justice system or known foreign definition criminal 
justice system has proven this process effectively and efficiently. Ramington and Ohlin's views put forward:

"Criminal justice system" is administratively interpreted by using procedures or procedural law in the courts, which in turn this procedure functions as a means to establish relations of laws, administrative and social behavior. Pragmatically and efficiently, the definition is part of the results of a correlation in order to produce a limitative value". ${ }^{21}$

Hagan gives a different meaning to "criminal justice processes" and "criminal justice system". Criminal Justice System Proccess which is the result of a court decision which is then confronted with the perpetrator of the crime and delivers it to the provisions of a criminal act. The Criminal Justice System is the connection of a decision from a law enforcement agency, especially legal procedures in the court. ${ }^{22}$ The definition of criminal justice system in a limited scope is the operation of subsystems in the enforcement of criminal law legal advisors, police, prosecutors, courts, and correctional institutions. While the notion of the criminal justice system in the broad sense of the workings of sub-systems in society to overcome crime by means of criminal law and facilities outside criminal law.

Technical procedures in the scope of the court can be interpreted as procedures for solving a dispute problem in locations where victims, citizens and perpetrators of crime. The parties to the conflict are given space and place to find the best solution due to legal actions. Thus the involvement of the parties, especially victims, is the most important part with the consideration that victims, community members and perpetrators of crime are central. This was done with the aim of creating mediation and building peace. ${ }^{23}$ We think it is important first to present a general description of the criminal justice system in order to provide an overview of the stages in the context of legal procedures. The existence of victims in the context of criminal law is a unity of legal procedures, because the existence of victims will have implications for the recognition of the interests of victims. Therefore, it is necessary

\footnotetext{
${ }^{21}$ Romli Atmasasmita, Sistem Peradilan Pidan Kontemporer (Kencana 2011).[2].

22 ibid.

${ }^{23}$ Rena Yulia, Viktimologi Proteksi Hukum Terhadap Korban Kejahatan (Graha Ilmu 2013).
} [188-191]. 
to empower the position of victims in the criminal justice system as a substantial legal protection effort. ${ }^{24}$ Departing from such thinking, our criminal justice system should accommodate the form of victim involvement at every stage of the judiciary.

Regarding the form of victim involvement in the juvenile justice system, of course, it must be based on the best interests of victims and child victims by seeking a family atmosphere that is well maintained so as not to cause fear of victims and victims' children. UU No. 11 of 2012 also emphasizes for the safety and comfort of child victims, every process of investigation and investigation (investigation) in law enforcement agencies, should be guided or escorted by their parents and/or guardians.

A deeper discussion is to discuss the form of victim involvement in Law No. 11 of 2012 , both at the stage of investigation, prosecution and trial of the victim's involvement only as a witness but from the process of being a witness, there are several ways in which legal protection, especially for children, is the confidentiality of both printed publications and online. ${ }^{25}$ This kind of protection is important in order to avoid labeling children victims, especially children who are not yet mature or under eighteen.

WagiatiSoetodjo ${ }^{26}$ expressingabout fostering children as theyoungergeneration is a form of actualization and legal protection of children. Learning facilities for children are part of the goal of national reform and to create a prosperous, just and prosperous citizen. The concept of protection for children includes discussion in a broad sense. That is, this protection is not only about protection of the body and soul, but also includes all the interests of the child including the rights of the child. Referring to the form of victim participation in the criminal justice process, there is something interesting according to the author because at the trial stage, before the verdict was handed down, the judge first gave the child time to present his trade on

\footnotetext{
${ }^{24}$ Rena Yulia, 'Restorative Justice Sebagai Alternatif Proteksi Hukum Terhadap Korban Kekerasan Dalam Rumah Tangga' (2009) 39 Jurnal Hukum Dan Pembangunan < http://jhp.ui.ac.id/ index.php/home/article/view/209>.[62].

${ }_{25}$ See Article 19 section $1 \& 2$ of Law No. 112012 on Children Criminal Justice.

${ }^{26}$ Wagiati Soetodjo, Hukum Pidana Anak (Refika Aditama 2006).[55].
} 
the problems faced by the child. Such a model can indicate two things, first, that lawmakers give victims the opportunity to express their opinions regarding the case for the fulfillment of victims' justice or even justice for perpetrators of criminal acts. Second, that lawmakers provide opportunities for victims, especially children of victims, to convey all matters relating to the case concerned that do not rule out the possibility of fulfilling the rights of victims. Law No. 11/2012 also gives rights to child victims as follows:

a. The rights to obtain health and community rehabilitation both on the willingness of coaching in institutions or outside institutions;

b. The rights to get physical, mental and social safety guarantees;

c. The rights to receive information about legal issues faced;

d. The rights to obtain legal protection from the institution of victim witness protection.

If you look at the forms of involvement of victims and child victims in the criminal justice process based on Law No. 11 of 2012 concerning the Child Criminal Justice System, it is only focused on the child victims about how the form is specifically involved in the criminal justice process. Special attention to child victims, according to the author, is inseparable from the skills of the child victims, because it is still categorized as an immature person. Therefore, special attention to the child victims is in line with the spirit of the establishment of Law No. 11 of 2012.

\section{Conclusion}

Based on the discussion above, it can be concluded that first, access to victims of criminal acts in Law No. 11/2012 which is in the concept of restorative justice. The restorative justice model offered in Law No. 11/2012 is an open door for victims of criminal acts to fight for their rights as victims. Humanly speaking, the nature of the recotration refers to the linkages between victims and offenders. This statement applies not only to victims, but also to offenders. The idea of justice restoration has become one of the most contemporary theories that no longer ignores the interests of the victims, but become an integral part of the juvenile justice system. Second, in Law No. 11/2012, the term diversion is defined as the transfer of legal processes/procedures of children from the court to the process outside of criminal law courts. While the concept of diversion 
itself is a theory that connects the parties to the dispute/conflict with regard to their rights and obligations to produce the best solutions, improve relations with each other, and without bringing up revenge. If studied more deeply, diversion is a manifestation of the concept of restorative justice in which victims and perpetrators of crimes are brought together to reach a solution to problems that benefit all parties. In this process, the victim can be actively involved to express their opinion on a crime so as to come with the best possible outcome.

Third, the form of victim's involvement in the criminal justice process is as a victim witness. Victim witnesses here also receive legal protection by protecting the identity of victims from all forms of media publications so as to prevent victims from being targeted. The next form of victim involvement in the criminal justice system is before the judge deciding on the victim's child to be given the opportunity to submit an opinion on the ongoing case. Such procedures can fulfill the conditions of both victims and offenders. This process also provides an opportunity for victims, especially child victims, to convey all matters relating to the case in question

\section{Bibliography}

Adhi Wibiwo, Proteksi Hukum Korban Amuk Massa Sebuah Tinjauan Viktimologi (Thafa Media 2013).

Arif Gosita, Masalah Proteksi Anak (Akademika Presindo 1989).

__, Masalah Korban Kejahatan (Akademika Presindo 1993).

Bambang Waluyo, Viktimologi Proteksi Saksi Dan Korban (Sinar Grafika 2012).

Dikdik M Haris Mansyur And Elisatris Gultom, Urgency for Protection of Victims of Crime: Between Norms and Reality (Raja Grafindo 2008).

O.S. Hiariej, Prinsip-Prinsip Hukum Pidana (Universitas Atma Jaya 2014).

Ig Punia Atmaja Nr, 'Penyiaran Berita Kriminal Dalam Kerangka Proteksi Hak Tersangka Atau Terdakwa' (2017) 32 Yuridika <https://e-journal.unair.ac.id/ YDK/article/view/4853>.

Karim, ‘Tanggung Jawab Pelaku Pidana Pelanggaran Dalam Perspektif Restorative 
Justice' (2016) 31 Yuridika <https://e-journal.unair.ac.id/YDK/article/ view/4787>.

Law Number 8 Year 1981 on the Criminal Procedure Code (KUHAP). (State Gazette of the Republic of Indonesia of 1982 Number 76).

Law Number 11 Year 2012 On Children Criminal Justice System (State Gazette of the Republic of Indonesia of 2012 Number 153).

Marlina, 'Penerapan Konsep Diversi Terhadap Anak Pelaku Tindak Pidana Dalam Sistem Peradilan Pidana Anak' (2008) 13 Jurnal Equality <http:// repository.usu.ac.id/bitstream/handle/123456789/18420/equ/-feb2008-13 (5). pdf;jsessionid=6ACBDA73585C95838A9E82A2DFB3EC16? sequence=1>.

Peter Mahmud Marzuki, Penelitian Hukum (Revisi, Kencana Prenada Media Group 2013).

Rena Yulia, 'Mengkaji Kembali Posisi Korban Kejahatan Dalam Sistem Peradilan Pidana' (2016) 28 Mimbar Hukum <https://jurnal.ugm.ac.id/jmh/article/ view/15858/10467>.

—_, 'Restorative Justice Sebagai Alternatif Proteksi Hukum Terhadap Korban Kekerasan Dalam Rumah Tangga' (2009) 39 Jurnal Hukum Dan Pembangunan $<$ http://jhp.ui.ac.id/index.php/home/article/view/209>.

—_, Viktimologi Proteksi Hukum Terhadap Korban Kejahatan (Graha Ilmu 2013).

Romli Atmasasmita, Sistem Peradilan Pidan Kontemporer (Kencana 2011).

Siswanto Sunarso, Viktimologi Dalam Sistem Peradilan Pidana (Sinar Grafika 2012).

Teguh Prasetyo and Abdul Halim Barkatullah, Politik Hukum Pidana (Pustaka Pelajar 2012).

Wagiati Soetodjo, Hukum Pidana Anak (Refika Aditama 2006).

Wisnubroto and Widiartana, Pembaharuan Hukum Acara Pidana (Citra Aditya Bakti 2005).

HOW TO CITE: Oheo K. Haris and Ali Risky, 'Victim's Involvement Model in Children Legal Process Based on Law No. 11/2012 on Children Criminal Justice System' (2019) 34 Yuridika. 